Ворон В. П., кандидат сільськогосподарських наук, Сидоренко С. Г., кандидат сільськогосподарських наук, Мельник $\epsilon$. $\epsilon$.,

Коваль І. М., кандидат сільськогосподарських наук

Український науково-дослідний інститут лісового господарства та агролісомеліорації ім. Г. М. Висоцького

\title{
ЗАПАСИ ЛІСОВОЇ ПІДСТИЛКИ ПРИМІСЬКИХ ЛІСІВ ХАРКІВЩИНИ ЯК ОСНОВНОГО ГОРЮЧОГО МАТЕРІАЛУ В ЧИСТИХ СОСНЯКАХ
}

\author{
Рецензент - доктор сільськогосподарських наук В. Л. Мсшкова
}

Мета статті - виявити особливості кількісних і якісних змін у лісовій підстилці чистих сосняків зелених зон міста Харків із віком, що впливають на пожежну небезпеку.

Методика дослідження. Дослідження проведено у чистих одновікових сосняках різного віку, що ростуть в умовах свіжого субору, на 9 пробних площах. На кожній пробній площі підстилку для аналізу відбирали на 9 площадках площею $1 \mathrm{~m}^{2}$ за мікрозонами - під стовбуром, на межі крони та у міжкроновому просторі. Запаси підстилки визначали зважуванням усієї маси кожного з шарів мінералізації, після чого відбирали середні зразки, які висушували у лабораторних умовах до повітряносухого стану. Одержані дані аналізували статистично методами варіаційної статистики, кореляиійного регресійного аналізу.

Результати дослідження. Встановлено, щуо товщина підстилки становила від 0,7 до 10,3 см та достовірно збільшувалася з віком насадження. Виявлено тренд збільшення запасу лісової підстилки з віком насаджень від 172,2 до 675,9 и/га. Виявлено, щзо частка нижнього гуміфікованого шару збільшується з віком, особливо інтенсивно відбувається його акумулячія з 35 до 82 років. У перестійних сосняках запас підстилки помітно мінімізується, через зниження повноти насадження та зменшення щорічного надходження хвої з опадом. Вологість підстилки достовірно відрізнялася за шарами: найнижча - в опадовому, найвища - у нижньому гуміфікованому.

Елементи наукової новизни. Вперше висвітлено закономірності накопичення та розподілу лісових горючих матеріалів у найбільш пожежонебезпечних приміських сосняках Харківщини.

Практична значущість. Прогнозування ймовірності виникнення, розвитку та поведінки пожежі $\epsilon$ неможливим без достовірних даних щзодо закономірностей накопичення різних типів лісових горючих матеріалів (ЛГМ) та динаміки їхньої вологості, тому вивчення ЛГМ є першочерговим завданням пірологічних досліджень в Україні.

Ключові слова: рослинні горючі матеріали, характеристики лісових горючих матеріалів, об'ємна мaca.

Ворон Володимир Пантелеймонович - кандидат сільськогосподарських наук, старший науковий співробітник, завідувач лабораторії екології лісу, Український науково-дослідний інститут лісового господарства та агролісомеліорації ім. Г. М. Висоцького, вул. Пушкінська, 86, м. Харків, 61024, Україна, е-mail: 52_corvus@gmail.com.

Сидоренко Сергій Григорович - кандидат сільськогосподарських наук, старший науковий співробітник лабораторії екології лісу, Український науково-дослідний інститут лісового господарства та агролісомеліорації ім. Г. М. Висоцького, вул. Пушкінська, 86, м. Харків, 61024, Україна, e-mail: sydorenkosg@uriffm.org.ua, serhii88sido@gmail.com.

Мельник Євген Євгенович - науковий співробітник лабораторії екології лісу, Український науково-дослідний інститут лісового господарства та агролісомеліорації ім. Г. М. Висоцького, вул. Пушкінська, 86, м. Харків, 61024, Україна, e-mail: Wudckij@bigmir.net.

Коваль Ірина Михайлівна - кандидат сільськогосподарських наук, старший науковий співробітник, провідний співробітник лабораторії екології лісу, Український науково-дослідний інститут лісового господарства та агролісомеліорації ім. Г. М. Висоцького, вул. Пушкінська, 86, м. Харків, 61024, Україна, e-mail: koval_iryna@ukr.net. 


\section{СІЛЬСЬКЕ ГОСПОДАРСТВО. РОСЛИННИЦТВО}

Постановка проблеми. Нині особливої актуальності набувають лісопірологічні дослідження. Лісова пірологія в Україні все ще перебуває в зародковому стані. Умовно “ї поділяють на три основні напрями: моделювання виникнення та поведінки пожеж, дослідження лісових горючих матеріалів (ЛГМ) та впливу вогню на екосистеми (fire ecology). Моделювання поведінки пожеж спирається на дані про кількісні та якісні характеристики ЛГМ, рельєф і кліматичні умови. В Україні дослідження ЛГМ мають фрагментарний характер (різні лісорослинні умови, використання різних методик тощо). Дослідження характеристик, властивостей та особливостей формування лісових підстилок та інших наземних ЛГМ дасть змогу прогнозувати здатність ії до займання та потенційні післяпожежні ризики (інтенсивність відпаду дерев, імовірність заселення стовбуровими шкідниками тощо).

Аналіз останніх досліджень і публікацій, у яких започатковано розв'язання проблеми. За М. П. Курбатським [6] лісовими горючими матеріалами) є рослини та їхні залишки різного ступеня розкладання, які можуть горіти під час пожеж. У чистих сосняках основним та найбільш легкозаймистим горючим матеріалом $\epsilon$ лісова підстилка [7]. Температура горіння лісової підстилки залежить від іï товщини, маси, вологості, щільності (об’ємна маса) та безперервності їі покриву [7]. Температура горіння верхнього опадового, ферментативного та гуміфікованого шарів сильно відрізняється. Найвищу температуру горіння має середній ферментативний шар, а найнижчу - гуміфікований [4]. Найбільш важливими якісними характеристиками, що впливають на режим горіння лісової підстилки, є іï вологість [8], щільність [6], запас, співвідношення поміж шарами мінералізації та фракційний склад [1]. За фракційним складом основою мортмаси опадового шару (L) є опад хвої. Цей шар підстилки разом із трав'яним покривом [1] належить до I групи ЛГМ, які $є$ «провідниками горіння». Нині в Україні активно досліджують різні групи лісових горючих матеріалів (підземних, наземних, надземних) та вдосконалюють методики їхнього оцінювання. Лабораторією екології лісу досліджено тенденції в накопиченні наземних ЛГМ у вологих борах та суборах Українського Полісся [4]. Науковцями Національного університету біоресурсів і природокористування України (НУБіПУ) проведено аналогічні дослідження у поліських соснових лісах Відокремленого підрозділу Національного університету біоресурсів і природокористування України «Боярської лісової дослідної станції» (ВП «НУБіП
України «Боярська ЛДС»») [5]. Досліджено основні характеристики лісової підстилки у Поліських лісах, такі як: запас, товщина, об'ємна маса, вологість за шарами мінералізації тощо. Лабораторією лісової пірології Національного університету біоресурсів і природокористування України [3] розпочато створення комплексного пірологічного геопорталу для лісів українського Полісся з метою моделювання поведінки пожеж, попереднього оцінювання наслідків пожеж і визначення природної пожежної небезпеки. Одним iз основних наборів вхідних даних $є$ актуальна інформація щодо стану ЛГМ на конкретній лісовій ділянці. 3 огляду на це, одержання інформації щодо ЛГМ у лісах, що ростуть в інших природних зонах (Лісостепу та Степу), та в подальшому створення на базі досліджень регіональних моделей рослинних горючих матеріалів $є$ актуальною проблемою, вирішення якої дасть змогу в майбутньому прогнозувати поведінку пожеж по всій території України.

Мета роботи - дослідити кількісні та якісні характеристики лісової підстилки приміських лісів Харкова.

Завдання дослідження - виявити тенденції у накопиченні запасів підстилки, змін ії об'ємної маси та співвідношення шарів мінералізації залежно від віку сосняків зелених зон міста Харків.

Матеріали і методи. Дослідження проведено у чистих одновікових сосняках різного віку, що ростуть у свіжому суборі - найбільш поширеному та найбільш горимому типі лісорослинних умов [2] на 9 постійних пробних площах, закладених у Васіщевському лісництві ДП «Жовтневе ЛГ» та Південнмоу лісництві Харківської ЛНДС УкрНДІЛГА (табл. 1).

Облік підстилки на кожній пробній площі проводили на 9 площадках площею $1 \mathrm{~m}^{2}$, адже відомо, що розподіл лісової підстилки у насадженні $є$ дуже нерівномірним та залежить від мікрорельєфу, віддаленості від стовбура тощо. Тому для одержання достовірної інформації було проведено відбір підстилки за мікрозонами біля стовбурів (3 шт.), на межі крони (3 шт.) та у міжкроновому просторі (3 шт.). Зібрану підстилку розподіляли за шарами мінералізації. Запаси підстилки визначали за методикою Л. Є. Родіна [9]. Вологість і щільність підстилки за шарами може дуже відрізнятися, тому відібрані зразки розподіляли за шарами мінералізації: опадовим $L$; ферментативним $-F$; та гуміфікованим $-H$ [10]. 3 кожної пробної площі відібрано середні зразки за шарами, висушено до повітряно-сухого стану та вилучено пісок. Після камерально- 


\section{СІЛЬСЬКЕ ГОСПОДАРСТВО. РОСЛИННИЦТВО}

лабораторних робіт обраховані запаси лісової підстилки у перерахунку на 1 га площі. Під час аналізу даних використано стандартні методи варіаційної статистики, регресійного та кореляційного аналізу.

Результати досліджень. У результаті проведеного аналізу повітряно-сухих зразків лісової підстилки встановлено, що у соснових насадженнях, які ростуть у свіжих суборах зелених зон міста Харків (табл. 2), накопичуються значні запаси підстилки - від 172,7 до 675,9 ц/га. Товщина підстилки варіювала від 0,7 до 10,3 см і збільшувалася 3 віком насадження $(r=0,8$; $p=0,05)$, так у віці 9 років iї середня товщина становила 1,2 см, а у віці 124 роки - 6,4 см (табл. 2).
Виявлено, що найбільший запас підстилки накопичується біля стовбура дерева (160,0-848,1 ц/га), а найменший - у вільному просторі між кронами дерев, де накопичення опаду хвої було мінімальним або взагалі відсутнім (0-565,4 ц/га). Ці результати узгоджуються 3 раніше одержаними у Поліському регіоні [4]. Запас підстилки під кроною має проміжне положення. Різниця в товщині підстилки залежно від локації збору може сягати 200-250\% і є статистично значущою $\left(F_{f}=3,71 ; F_{t}=3,20 ; p=0,05\right)$. Потужність (товщина) підстилки у межах лісостану також $є$ нерівномірною та залежить від локації збору. Біля стовбура товщина підстилки становила від 1,7$10,3 \mathrm{~cm}$, а у міжкроновому просторі - від 0 до 3,9 см $\left(F_{f}=4,32 ; F_{t}=3,46 ; p=0,05\right)$.

\section{1. Характеристика чистих сосняків свіжого субору (Васіщевське лісництво ДП «Жовтневе ЛГ» ПП1-8 та Південне лісництво Харківська ЛНДС ПП 9)}

\begin{tabular}{|c|c|c|c|c|c|c|c|c|}
\hline $\begin{array}{r}\text { № } \\
\Pi \Pi \Pi^{*}\end{array}$ & 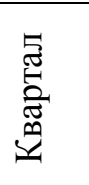 & 㫡 & 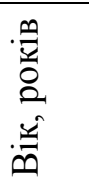 & 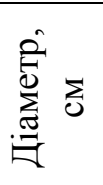 & 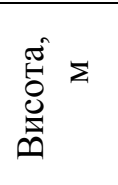 & 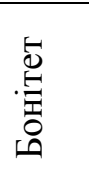 & 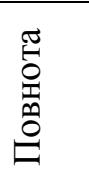 & 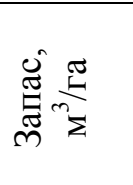 \\
\hline 1 & 123 & 6 & 10 & 10 & 4,3 & 1 & 0,85 & 12 \\
\hline 7 & 91 & 5 & 17 & 8 & 7,6 & 1 & 1,00 & 26 \\
\hline 2 & 112 & 10 & 24 & 14 & 10,0 & $1 \mathrm{~A}$ & 0,75 & 115 \\
\hline 9 & 159 & 5 & 35 & 16 & 13,2 & 1 & 0,80 & 144 \\
\hline 3 & 99 & 6 & 55 & 28 & 16,0 & 2 & 0,75 & 217 \\
\hline 8 & 103 & 2 & 63 & 24 & 17,8 & 2 & 0,79 & 270 \\
\hline 4 & 99 & 4 & 72 & 28 & 24,2 & 1 & 0,80 & 433 \\
\hline 5 & 115 & 3 & 82 & 29 & 22,6 & 2 & 0,75 & 389 \\
\hline 6 & 128 & 4 & 124 & 46 & 26,0 & 2 & 0,40 & 243 \\
\hline
\end{tabular}

Примітка: *ППП - постійна пробна площа.

Джерело: власні дослідження.

2. Запас і потужність лісової підстилки у чистих сосняках свіжсого субору (Васіщевське лісництво ДП «Жовтневого ЛГ» та Південне лісництво Харківської ЛНДС)

\begin{tabular}{|c|c|c|c|c|c|c|c|c|c|}
\hline \multirow{2}{*}{$\begin{array}{c}\text { № } \\
\text { ППП* }\end{array}$} & \multirow{2}{*}{$\begin{array}{c}\text { Класи } \\
\text { віку }\end{array}$} & \multicolumn{4}{|c|}{ Товщина підстилки, см } & \multicolumn{4}{c|}{ Запас підстилки, ц/га } \\
\cline { 3 - 9 } & стовур & крона & простір & $\begin{array}{c}\text { сере- } \\
\text { дні }\end{array}$ & стовбур & крона & простір & $\begin{array}{c}\text { сере- } \\
\text { дні }\end{array}$ \\
\hline 1 & I & 1,7 & 1,1 & 0 & 1,4 & 160,0 & 101,1 & відсутня & 130,6 \\
\hline 7 & II & 2 & 0,8 & 0,7 & 1,6 & 232,2 & 179 & 106,8 & 172,7 \\
\hline 2 & III & 2,2 & 2 & відсутня & 2,1 & 264,3 & 204,4 & відсутня & 234,3 \\
\hline 9 & IV & 2,3 & 1,1 & 0,7 & 2,3 & 482,3 & 375,0 & 200,2 & 352,5 \\
\hline 3 & VI & 5,5 & 2,3 & 3 & 3,6 & 512,1 & 401,3 & 415,5 & 443 \\
\hline 8 & VII & 6,7 & 3,6 & 2,6 & 4,3 & 567,2 & 452,3 & 409,4 & 476,3 \\
\hline 4 & VIII & 9,6 & 3,7 & 2,9 & 5,4 & 848,1 & 614,2 & 565,4 & 675,9 \\
\hline 5 & IX & 6,2 & 4,4 & 3,9 & 4,8 & 690,6 & 598,5 & 442,9 & 577,3 \\
\hline 6 & XIII & 10,3 & 5,3 & 3,5 & 6,4 & 463,5 & 321,6 & 320,7 & 368,6 \\
\hline
\end{tabular}

Примітка: *ППП - постійні пробні площі.

Джерело: власні дослідження. 


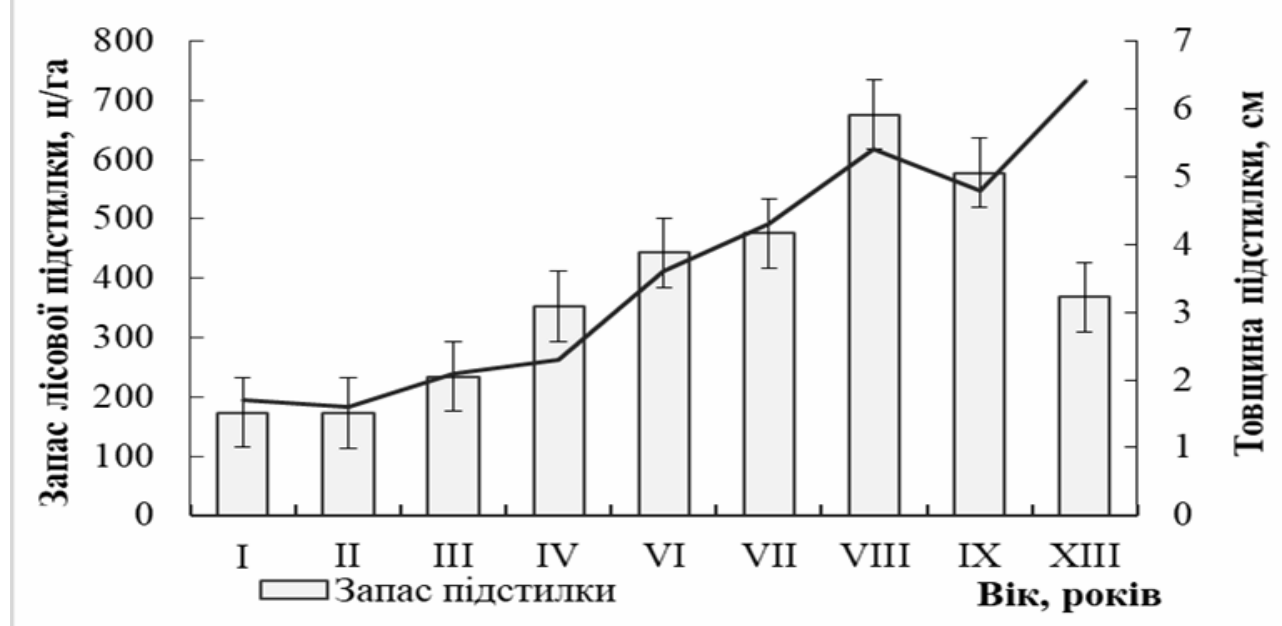

Рис. 1. Зміна запасу й товщини лісової підстилки з віком у сосняках приміських лісів Харкова

\section{Джерело: власні дослідження.}

Запас підстилки і потужність їі змінювалися з віком насадження (рис. 1). Під час кореляційного аналізу виявлено сильний прямий зв'язок між запасом лісової підстилки та віком насадження $(r=0,78$, $p=0,05)$. Регресійний аналіз виявив, що цю залежність найкраще апроксимує логарифмічна функція:

$$
\mathrm{M}=159,19 \times \ln (\mathrm{A})-208,34 \text {, }
$$

де $M$ - запас лісової підстилки ц/га, $A$ - вік насадження, років.

Коефіцієнт детермінації $R^{2}=0,61$ свідчить, що у $61 \%$ випадків загальний запас підстилки визначається віком насадження. Накопичення значної кількості підстилки в соснових лісостанах Лівобережного Лісостепу вказує на потенціал збільшення інтенсивності пожеж та наростання їхнього негативного впливу на сосняки старшого віку. Отже, збільшення запасів лісової підстилки зі зростанням віку та значне ії накопичення біля основ стовбурів дерев під час пожежі призводять до локального збі- льшення інтенсивності горіння та значних пошкоджень прикореневої частини стовбура.

Співвідношення між шарами гуміфікації лісової підстилки у процесі розвитку лісостану помітно змінюється (рис. 2). До 55 років у насадженнях частки шарів $L$ і $F$ майже однакові, а частка нижнього $H$ незначна або зовсім відсутня. У насадженнях віком понад 50 років частка гуміфікованого шару підстилки різко зростає (рис. 2), сягаючи піку у 72 річному віці (479,8 ц/га) і поступово зменшуючись до віку 124 років (до 233,9 ц/га) через зниження повноти насадження та зменшення щорічного надходження хвої з опадом.

У пристигаючих і стиглих сосняках зафіксоване суттєве зростання запасів ферментативного та гуміфікованого шарів підстилки, що за умов тривалої посухи надалі збільшуватиме пожежні ризики та посилить негативний вплив на пошкоджені насадження.

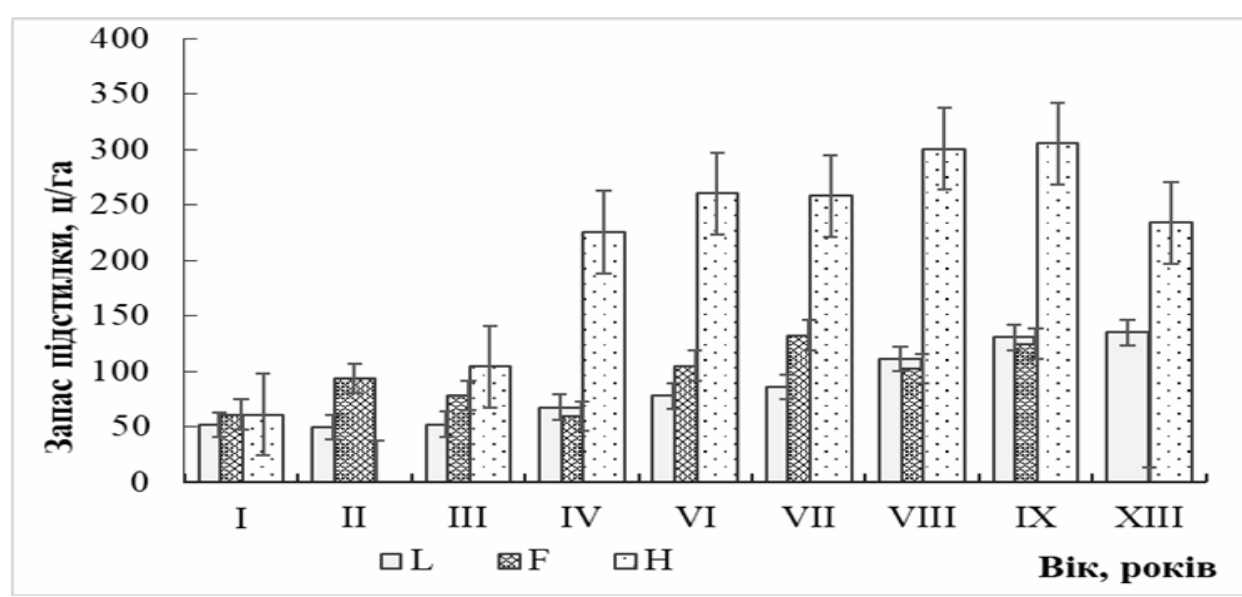

Рис. 2. Зміна запасу різних шарів підстилки в соснових насадженнях зелених зон м. Харків

Джерело: власні дослідження. 


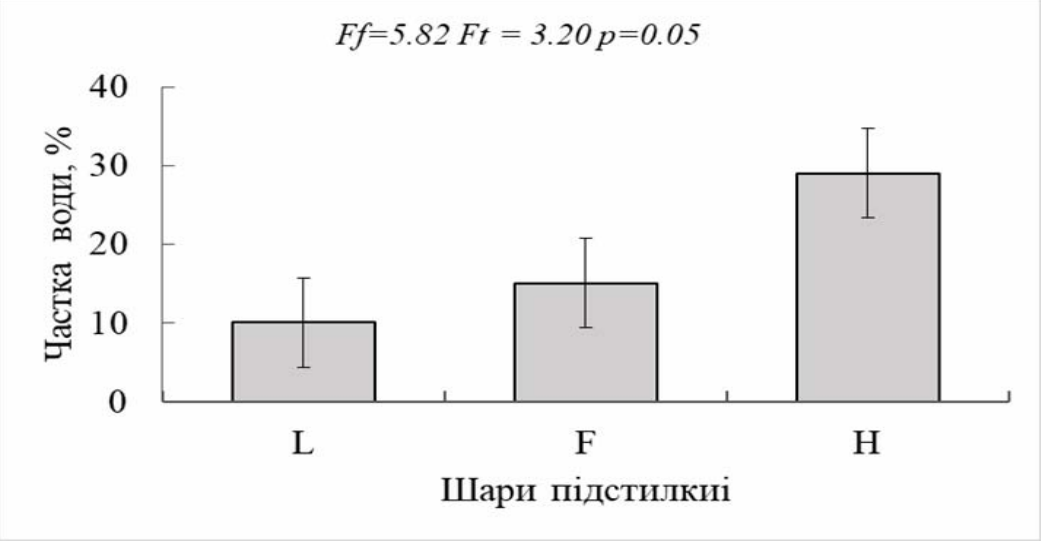

Рис. 3. Вологість різних шарів підстилки у сосняках зелених зон м. Харків

Джерело: власні дослідження.

Вологість шарів підстилки також відрізнялася (рис. 3). Мінімальну вологість відмічено в опадовому шарі (10 \%), а найвищу (29\%) - у гуміфікованому. Під час дисперсійного аналізу виявлено, що відмінності у вологості різних шарів підстилки були статистично достовірними $\left(F_{f}=5,82 ; F_{t}=3,20 ; p=0,05\right)$.

Можливість загорання підстилки залежить насамперед від іiі вологості. Отже, вологість верхнього шару підстилки може бути меншою майже втричі порівняно з нижнім гуміфікованим. Це часто призводить до вигорання лише верхнього шару лісової підстилки (так звані рухливі низові пожежі), тоді як нижні вологіші шари постають у ролі теплоізоляційного буферу, запобігаючи пошкодженню тканин дерев у нижній частині стовбура. За даними В. Г. Нестерова [8] загорання лісової підстилки можливе лише за вологості менше $30 \%$, тобто на момент відбору підстилка у разі низової пожежі могла цілком вигоріти.

Під час регресійного аналізу встановлено, що на $97 \%$ середній у насадженні запас підстилки визначався іiі середньою товщиною $\left(R^{2}=0,97\right.$; $p=0,05)$ та на $3 \%$ іншими факторами. Під час побудови регресійної моделі не було включено дані з ПП 6 (124-річний сосняк), оскільки підстилка мала аномально низьку об'ємну масу, що пов'язане зі зрідженням насадження до повноти 0,45 . Отримане регресійне рівняння (2) дає змогу

\section{БІБЛІОГРАФІЯ}

1. Волокитина А. В., Софронов М. А. Классификация растительных горючих материалов. Лесоведение. 1996. № 3. С. 38-44.

2. Ворон В. П., Мельник С. С., Сидоренко С. Г. Тенденції виникнення пожеж в лісах зеленої зони м. Харків. Проблемы пожарной безопасности. 2012. № 32. С. 37-42.

3. Гуржій Р. В., Яворовський П. П. Запаси на- попередньо оцінити запаси підстилки для всього насадження з урахуванням ії товщини (у повітряно-сухому стані):

$$
\mathrm{M}=122,1 \times \mathrm{H}-4,0941 \text {, }
$$

де $M$ - запас лісової підстилки у повітряносухому стані, ц/га;

$H$ - товщина шару лісової підстилки, см.

Висновок. Запаси підстилки у приміських соснових лісостанах м. Харків збільшуються 3 віком (від 136 до 675,9 ц/га) та залежать від локації відбору у насадженні (запас підстилки зменшується зі збільшенням відстані від стовбура дерева). Запас лісової підстилки збільшується 3 віком і сягає піку у 72 річних сосняках $(675,9$ ц/га), після чого починає зменшуватися до 577,3 ц/га у 82 роки та до 368,6 ц/га у 124 роки. Запропоновано дві регресійні моделі, за якими можливо визначати запаси лісової підстилки за іiі товщиною та віком.

Найбільший запас підстилки акумулюється біля стовбура, а найменший - у вільному від крон просторі. Вологість, щільність і співвідношення за запасом окремих шарів мінералізації лісової підстилки суттєво відрізняються. Вологість найнижчого гуміфікованого шару майже втричі більша, ніж опадового, а запас у 2-3 рази перевершує опадовий. 3 віком запас гуміфікованого шару стрімко зростає і сягає максимуму у сосняків дев'ятого класу віку.

земних лісових горючих матеріалів у лісах Київського Полісся. Лісівництво і агролісомеліорація. 2018. №. 132. С. 124-130.

4. Запаси підстилки та живого надгрунтового покриву як показник ризику виникнення пожеж у соснових лісах Полісся / Ворон В. П., Ткач О. М., Сидоренко С. Г. та ін. Наукові праиі Лісівничої академї наук Украӥни. Збірник науко- 
вих праць. РВВ НЛТУ України. 2018. № 16. C. 9-16.

5. Зібиев С. В., Миронюк В. В., Богомолов В. В., Сошенський О. М., Гуменюк В. В., Корень $B$. A. Перехід від проекту протипожежного впорядкування до системи підтримки прийняття рішень в рамках інтегрованої системи управління пожежами. Проблеми розвитку лісової таксачії, лісовпорядкування та інвентаризачії лісів. Київ, 2018. С. 58-60.

6. Курбатский Н. П. Исследование количества и свойств лесных горючих материалов. Bonросы лесной пирологии. 1970. С. 5-58.

\section{REFERENCES}

1. Volokitina, A. V. \& Sofronov, M. A. (1996). Klassifikacija rastitel'nyh gorjuchih materialov. Lesovedenie [Classification of vegetable combustible materials]. Forestry, 3, pp. 38-44 [In Russian].

2. Voron, V. P., Melnyk, Ye. Ye. \& Sydorenko, S. H. (2012). Tendentsii vynyknennia pozhezh v lisakh zelenoi zony m. Kharkiv. [Trends in the emergence of fires in the forests of the green zone of Kharkiv]. Fire safety issues, 32, pp. 37-42 [In Ukrainian].

3. Hurzhii, R. V. \& Yavorovskyi, P. P. (2018). Zapasy nazemnykh lisovykh horiuchykh materialiv $\mathrm{u}$ lisakh Kyivskoho Polissia [Reserves of forest fuels in the pine stands of the Kiev Polissya]. Forestry and Forest Melioration, 132, pp. 124-130 [In Ukrainian].

4. Voron, V. P., Tkach, O. M., Sydorenko, S. H., Melnyk, Ye. Ye. (2018). Zapasy pidstylky ta zhyvoho nadgruntovoho pokryvu yak pokaznyk ryzyku vynyknennia pozhezh u sosnovykh lisakh Polissia [Stock of litter as an indicator of the risk of fires in the pine forests of Polissya]. Scientific works of the Forestry Academy of Sciences of Ukraine. Collection of scientific works, 16. pp. 9-16 [In Ukrainian].

5. Zibtsev, S. V., Myroniuk, V. V., Bohomolov, V. V., Soshenskyi, O. M., Humeniuk, V. V., Koren, V. A. (2018). Perekhid vid proektu protypozhezhnoho vporiadkuvannia do systemy pidtrymky pryiniattia rishen $\mathrm{v}$ ramkakh intehrovanoi
7. Левченко В. В., Борсук О. А., Борсук А. А. Лісові горючі матеріали: навчальний посібник. Київ : НУБІП України, 2015. 237 с.

8. Нестеров В. Г. Пожарная охрана леса: монография. Москва : Гослестехиздат, 1945. 175 с.

9. Родин Л. Е., Базилевич Н. И. Динамика органического вещества и биологический круговорот в основних типах растительности: монография. Москва : Наука, 1965. 254 с.

10. Чорнобай Ю. М. Трансформація рослинного детриту в природних екосистемах : монографія. Львів : ДПМ НАН України. 2000. 352 с.

systemy upravlinnia pozhezhamy [Switching from a fire prevention project to a decision support system within the integrated fire management system]. Problems of forest tax development, forest management and inventory of forests. Kyiv, pp. 58-60 [In Ukrainian].

6. Kurbatskij, N. P. (1970). Issledovanie kolichestva i svojstv lesnyh gorjuchih materialov. Voprosy lesnoj pirologii. [Investigation of the quantity and properties of forest combustible materials]. Issues of forest pyrology, pp. 5-58 [In Russian].

7. Levchenko, V. V., Borsuk, O.A. \& Borsuk, A. A. (2015). Lisovi horiuchi materialy: navchalnyi posibnyk [Forest fuel: tutorial]. Kyiv : NUBIP of Ukraine [In Ukrainian].

8. Nesterov, V. G. (1945). Pozharnaja ohrana lesa : monografija [Fire protection of the forest: a monograph]. Moscow: Goslestehizdat [In Russian].

9. Rodin, L. E. \& Bazilevich, N. I. (1965). Dinamika organicheskogo veshhestva $i$ biologicheskij krugovorot $v$ osnovnih tipah rastitel'nosti: monografija [Dynamics of organic matter and biological cycle in the main types of vegetation: monograph]. Moscow: Nauka [In Russian].

10. Chornobai, Yu. M. (2000). Transformatsiia roslynnoho detrytu $v$ pryrodnykh ekosystemakh : monohrafiia. [Transformation of plant detritus in natural ecosystems: monograph]. Lviv: DPM NAN Ukraine [In Ukrainian].

\section{Ворон В. П., Сидоренко С. Г., Мельник С. С., Коваль І. М. Запасы лесной подстилки пригород- ных лесов Харькова как основной горючий материал в чистых сосняках}

Цель статьи - выявить особенности количественных и качественных изменений в лесной подстилке чистых сосняков зеленых зон города Харьков с возрастом, влияющие на ее пожарную опасность.

Материалы и методы. Исследование проведено в чистых одновозрастных сосняках разного возраста, растущих в условиях свежей субори, на 9 пробных площадях. На каждой пробной площади 
подстилку для анализа отбирали на 9 небольщих территориях площадью $1 \mathrm{M}^{2}$ по микрозонам - под стволом, на границе кроны и в межкроновом пространстве. Запасы подстилки определяли взвешиванием всей массы каждого из слоев минерализации, после чего отбирали средние образиы, которые высушивали в лабораторных условиях до воздушно-сухого состояния. Полученные данные анализировали статистически методами вариаџионной статистики, коррелящионного и регрессионного анализа.

Результаты исследования. Установлено, что толщина подстилки составляла от 0,7 до 10,3 см и достоверно увеличивалась с возрастом насаждения. Выявлен тренд увеличения запаса лесной подстилки с возрастом насаждений от 172,2 до 675,9 ир/га. Установлено, что доля нижнего гумифииированного слоя увеличивается с возрастом, особенно интенсивно происходит его накопление с 35 до 82 лет. В перестойных сосняках фонд подстилки заметно минимизируется из-за снижения полноты насаждения и уменьшения ежегодного поступления хвои с осадками. Влажность подстилки достоверно отличалась по слоям: самая низкая - в опадовом, самая высокая - в нижнем гумифицированном.

Элементы научной новизны. Впервые представлены закономерности накопления и распределения лесных горючих материалов в наиболее пожароопасных пригородных сосняках Харьковщины.

Практическая значимость. Прогнозирование вероятности возникновения, развития и поведения пожара невозможно без достоверных данных о закономерностях накопления различных типов лесных горючих материалов (ЛГМ) и динамики их влажности. Исходя из этого, изучение ЛГМ является первоочередной задачей пирологических исследований в Украине.

Ключевые слова: растительные горючие материаль, характеристики лесных горючих материалов.

Ворон Владимир Пантелеймонович - кандидат сельскохозяйственных наук, старший научный сотрудник, заведующий лабораторией экологии леса, Украинский научно-исследовательский институт лесного хозяйства и агролесомелиорации им. Г. Н. Высоцкого, ул. Пушкинская, 86, г. Харьков, 61024, Украина, e-mail: 52_corvus@gmail.com.

Сидоренко Сергей Григорьевич - кандидат сельскохозяйственных наук, старший научный сотрудник лаборатории экологии леса, Украинский научно-исследовательский институт лесного хозяйства и агролесомелиорации им. Г. Н. Высоцкого, ул. Пушкинская, 86, г. Харьков, 61024, Украина, e-mail: sydorenkosg@uriffm.org.ua, serhii88sido@gmail.com.

Мельник Евгений Евгеньевич - научный сотрудник лаборатории экологии леса, Украинский научно-исследовательский институт лесного хозяйства и агролесомелиорации им. Г. Н. Высоцкого, ул. Пушкинская, 86, г. Харьков, 61024, Украина, e-mail: Wudckij@bigmir.net.

Коваль Ирина Михайловна - кандидат сельскохозяйственных наук, старший научный сотрудник, ведущий сотрудник лаборатории экологии леса, Украинский научно-исследовательский институт лесного хозяйства и агролесомелиорации им. Г. Н. Высоцкого, ул. Пушкинская, 86, г. Харьков, 61024, Украина, e-mail: koval_iryna@ukr.net.

Voron V. P., Sydorenko S. H., Koval I. M., Melnyk Ye. Ye. Forest litter reserves in the suburban forests of Kharkiv region as a main forest fuel in pure pine forests

The purpose of the article was to investigate quantitative and qualitative changes in the forest litter under pure pine forests of the green areas of Kharkiv depending on the age.

The methods of research. The research was carried out in pure pine forests of different ages. The recording of litter on each experimental plot was carried out on 9 plots having the area of $1 \mathrm{~m}^{2}$, for obtaining reliable information, the litter was selected on micro-zones - under the tree trunk, on the boundary of the crown and in the inter-crown space.

The research results. It was established that the thickness of the litter varied from 0.7 to $10.3 \mathrm{~cm}$ and significantly increased with the age of tree. The tendency was revealed in increasing the reserve of forest litter with the age from 17.2. to 67.6. t/ha. It was revealed that the proportion of the lower humified layer increases with age, especially intensively it is accumulated from 35 to 82 years. In 124 year old pine forests, the reserve of litter is significantly minimized, due to reduced planting completeness and the decrease in the annual needle supply from falling. Litter moisture content significantly differed in layers: the lowest - in the fallen, the highest - in the lower humified.

The elements of scientific novelty. For the first time, the conformities of accumulating and distributing 
forest fuel in the most fire-hazardous suburban pine forests of Kharkiv region have been highlighted.

Practical significance. Predicting the probability of fire occurrence, its development and behavior is impossible without reliable data based on the patterns of accumulating different types of forest fuel and the dynamics of their humidity. Thus, the investigation of forest fuel based on the above mentioned factors is a priority task of forest fire research in Ukraine.

Key words: plant combustible materials, characteristics of forest fuel, volumetric weight.

Voron Volodymyr Panteleimonovych - Corresponding Member of the Forestry Academy of Sciences of Ukraine, Candidate (PhD) of Agricultural Sciences, Senior Researcher, Head of the Forest Ecology Laboratory of the Ukrainian Research Institute of Forestry, Land and Forest Reclamation, 86, Pushkinska str., Kharkiv, 61024, Ukraine, e-mail: 52_corvus@gmail.com.

Sydorenko Serhiy Hryhorovych - Candidate $(\mathrm{PhD})$ of Agricultural Sciences, Senior Researcher of the Forest Ecology Laboratory of the Ukrainian Research Institute of Forestry, Land and Forest Reclamation, 86, Pushkinska str., Kharkiv, 61024, Ukraine, e-mail: serhii88sido@gmail.com.

Melnyk Yevhen Yevhenovych - Researcher of the Forest Ecology Laboratory of the Ukrainian Research Institute of Forestry, Land and Forest Reclamation, 86, Pushkinska st., Kharkiv, 61024, Ukraine, e-mail: wudckij@bigmir.net.

Koval Iryna Mykhailivna - Candidate $(\mathrm{PhD})$ of Agricultural Sciences, Senior Researcher of the Forest Ecology Laboratory of the Ukrainian Research Institute of Forestry, Land and Forest Reclamation, 86, Pushkinska str., Kharkiv, 61024, Ukraine, e-mail: koval_iryna@ukr.net.

Стаття надійшла до редакції 27.02.2019 р.

\section{Бібліографічний опис для цитування :}

Ворон В. П., Сидоренко С. Г., Мельник С. С., Коваль І. М. Запаси лісової підстилки приміських лісів харківщини як основного горючого матеріалу в чистих сосняках. Вісник ПДАА. 2019. № 1. C. 27-34.

DOI 10.31210/visnyk2019.01.03

(C) Ворон Володимир Пантелеймонович, Сидоренко Сергій Григорович, Мельник Свген Свгенович, Коваль Ірина Михайлівна, 2019 